\title{
Socioeconomic Challenges of California Strawberry Production and Disease Resistant Cultivars
}

\author{
Julie Guthman $^{1 *}$ and Estelí Jiménez-Soto ${ }^{2}$ \\ ${ }^{1}$ Community Studies Program, Division of Social Sciences, University of California, Santa Cruz, Santa Cruz, CA, \\ United States, ${ }^{2}$ Department of Nutrition and Food Studies, David B. Falk College of Sport and Human Dynamics, Syracuse \\ University, Syracuse, NY, United States
}

\section{OPEN ACCESS}

Edited by: Helda Morales,

The South Border College

(ECOSUR), Mexico

Reviewed by:

Marta Astier,

National Autonomous University of Mexico, Mexico

Philippe V. Baret,

Catholic University of

Louvain, Belgium

${ }^{*}$ Correspondence:

Julie Guthman

jguthman@ucsc.edu

Specialty section:

This article was submitted to Agroecology and Ecosystem Services, a section of the journal Frontiers in Sustainable Food Systems

Received: 25 August 2021 Accepted: 21 October 2021 Published: 23 November 2021

Citation:

Guthman $J$ and Jiménez-Soto $E$ (2021) Socioeconomic Challenges of California Strawberry Production and Disease Resistant Cultivars. Front. Sustain. Food Syst. 5:764743 doi: 10.3389/fsufs.2021.764743
Strawberries are the 4th highest grossing crop in California and supply $90 \%$ of US strawberries. But the industry's long reliance on the use of chemical fumigants to control soil disease, nematodes and weeds is being threatened by increased regulation of these fumigants, leading to urgent efforts to develop and test non-chemical alternatives to fumigation, such as disease resistant cultivars. Many of these technologies are promising ecologically, but making them economically viable for growers is more challenging, especially in light of the socioeconomic context of strawberry production in California that has created a state of lock-in for a sustainability transition. This paper discusses how the challenges of land prices, labor shortages, marketing standards, and low prices bear on cultivar selection. Based on qualitative interviews, we corroborate that strawberry growers operate under significant socioeconomic constraints in California, many of which are beyond their control. In addition, we find that most growers see high-yielding varieties as crucial to their economic viability with regard to land, labor, and marketing intermediaries and yet recognize that the focus on individual farm productivity works at cross purposes to the problem of poor prices. Disease resistant varieties do not at face value address the concerns voiced by most growers. Our findings suggest, however, that if some of the other pressures were exogenously mitigated, growers might be more inclined to experiment with and adopt disease resistant varieties, in combination with other approaches. The most promising policy avenues seem to therefore lie with support of grower revenues.

Keywords: strawberry production-California, breeding-disease resistance, productivity treadmill, alternatives to methyl bromide, socioeconomic challenges, pesticide lock-in

\section{INTRODUCTION}

In a state long known for specialty crop production, strawberries have become a major player. Strawberries are the 4th highest grossing crop in California, bringing more than 2 billion dollars in revenue in $2020^{1}$. About $90 \%$ of US strawberries are grown in the state, which also exports up to $12 \%$ of the berries it grows ${ }^{2}$. Several coastal counties dominate strawberry fruit production, where

\footnotetext{
${ }^{1}$ Based on USDA Economic Research Service, September 2020 release. See: California Agricultural Statistics Review 2019-2020. Available at cdfa.ca.gov.

${ }^{2}$ California Strawberry Commission Export Reports are based on the U.S. Census Bureau; Trade Data Monitor; USDA-AMS; and PSAB. Available at calstrawberry.com.
} 


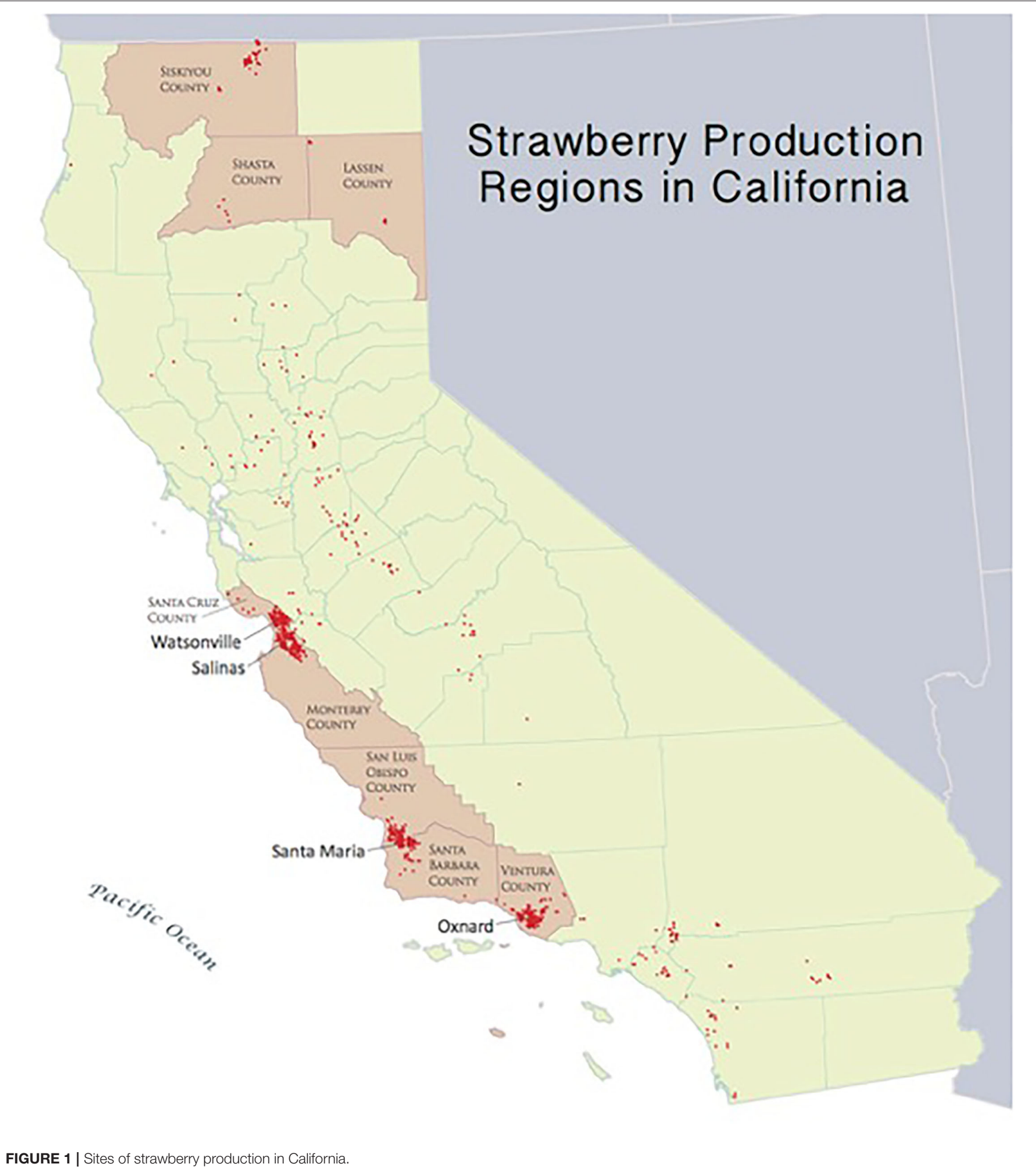

the sandy soils and temperate weather create nearly ideal conditions for commercial strawberry production, whereas the northern and inland areas are typically used for plant propagation (see Figure 1).
Strawberries have faced major sustainability challenges, however, including reliance on a suite of pesticides to control soil and plant disease, rot, mites, and other arthropods. Most notably, the industry has long been dependent on the use of chemical 
fumigants to control soil disease, especially the soil fungus Verticillium dahliae, as well as nematodes and weeds. The fifty year use of a combination of methyl bromide and chloropicrin made it possible for growers to plant on the same block year after year, without encountering significant plant damage. Many attribute the huge growth in the industry following the introduction of this combination in the late 1950s precisely to the use of these chemicals and related technologies such as plastic mulches (Wilhelm and Paulus, 1980; Baum, 2005). But in 1991, methyl bromide became subject to the international Montreal Protocol on Ozone Depleting Substances in 1991. Following years of successful efforts by the US to delay the mandated phaseout by obtaining Critical Use Exemptions (Gareau, 2008), the chemical was finally banned in 2016, except for nursery uses. Meanwhile, chloropicrin, was designated a toxic air contaminant, and another chemical used for soil fumigation, 1,3D (Telone), was deemed a carcinogen. These designations precipitated more stringent application protocols, taking the form of larger buffer zones and township caps, for example. A 2013 report issued by the California Department of Pesticide Regulation suggested that additional restrictions on fumigants might be forthcoming, especially given the increase in urban development near strawberry fields (Department of Pesticide Regulation, 2013). Concurrent with the onset of these increased restrictions, two "novel" soil pathogens, Macrophomina phaseolina and Fusarium oxysporum sp. fragariae, began regularly appearing in growers' fields, precipitating growing fears of significant die off (Koike et al., 2013; Tourte et al., 2016).

It is in the context of both increased regulation and novel pathogen outbreaks that for the last decade the California strawberry industry, with research support from the University of California and Cal Poly, have been urgently developing and testing for non-chemical alternatives to fumigation. These have included investments in anaerobic soil disinfestation, a method that involves using a carbon source and water to create soil anaerobicity and enhance the production of chemical byproducts for disease control, crop rotations that enhance microbial antagonists to suppress disease, and breeding disease resistant cultivars. As discussed by Brummer et al. (2011), plant breeding can be a powerful tool to support sustainability efforts, particularly in large-scale agriculture. Many of these technologies are promising ecologically (Holmes et al., 2020), but making them economically viable for growers is more challenging, especially in light of the socioeconomic context of strawberry production in California, which has been built on the presumption of continued fumigation (Gareau, 2008). Fumigation, as well as its accompanying technologies, effectively "locked in" an entire assemblage of technical and social relationships, resulting in both scientific and economic marginalization of more sustainable technologies (Magrini et al., 2016, 2018; Guthman, 2019).

In that light, this paper discusses how the major socioeconomic challenges experienced by California strawberry growers bear on commercial cultivar selection, with specific focus on disease resistant traits. We bring this focus as social scientists appended to a larger research project seeking to identify natural sources of resistance to pathogens affecting strawberries and accelerate the development of such cultivars. Disease resistant cultivars, while not a stand-alone solution, can arguably contribute to a "transition in the making"-one that does not necessarily effect a transformation, but can turn growers in more sustainable directions (Elzen et al., 2011, p. 263). Understanding what constrains their adoption-the sources of "lock-in"and what might be done to address them are thus important considerations (Magrini et al., 2018). Generally scholars have treated lock-in as function of path dependency stemming from wide scale adoption of an agricultural technology, such that the more it is adopted, the more its performance improves (Magrini et al., 2016). Pesticides as a technology are particularly prone to lock in for their ease of use and because they often boost yields for users, making for periods of initial high profitability until others adopt them and profit rates become re-normalized with lower prices (Wilson and Tisdell, 2001; Galt, 2013). Thereafter, uncertainties regarding the efficacy and social acceptance of more sustainable alternatives can stymie transitions to these methods (Cowan and Gunby, 1996; Wagner et al., 2016). Apropos to our research, in their study of wheat cultivar adoption, Vanloqueren and Baret (2008) found that growers were reluctant to adopt disease resistant varieties precisely because of these lock-in factors.

In the specific case of the California strawberry industry, soil disease was so rampant in the 1950s that fumigation with a combination of methyl bromide and chloropricrin saved the industry from near demise. Industry-wide productive increased sharply and consistently following wide-spread and quick adoption of this fumigation regime (Wilhelm et al., 1974). The ensuing lock-in, however, was not only a matter of path dependency per se, but also a set of political economic dynamics that evolved from the presumption of fumigation (Guthman, 2019). Facing pressures to move away from fumigation, California strawberry growers now confront this lock-in as a set of socio-economic challenges that make transitions to more sustainable methods quite difficult.

We thus couch our findings in prior research, including our own, on key areas of socio-economic challenges, which were corroborated through this research. These are: land availability and cost, labor availability and cost, the role of market intermediaries (shippers), and overall market conditions. Charged with understanding the socioeconomic conditions facing growers, we do not address how these challenges affect other stakeholders, most notably farmworkers as well as consumers and communities where strawberries are grown, but note that concerns of these stakeholders underpin some of the dynamics facing growers. So while we conclude by offering possible ways forward in mitigating these challenges, while also reducing the use of fumigants, we do not represent that these are whole cloth solutions to the many social and ecological challenges facing the California strawberry industry.

\section{METHODS}

According to the California Strawberry Commission, in 2020 there were $\sim 300$ strawberry growers in five distinct areas of 
California: Watsonville/Salinas, Santa Maria, Oxnard, Orange County/San Diego, and the Central Valley, growing on 34,167 acres, for an average of 342 acres per grower ${ }^{3}$. With estimated operating costs at $\$ 68 \mathrm{~K}$ per acre for conventional strawberries (Bolda et al., 2016) and more than $\$ 70 \mathrm{~K}$ per acre for organic systems (Bolda et al., 2019)—costs that have surely increased since these reports were completed-even a 100 acre operation is a huge capital investment. In actuality, some of these are very small operations of one or two acres, especially those in the Central Valley. Moreover, some of these are highly diversified farms, where berries are only a minor crop. Berries from both these sorts of operations tend to be marketed primarily, if not solely, through direct channels such as farmers' markets and farmstands.

The focus of this paper is commercial operations in which strawberries are one of the major crops grown and often the only crop grown. Offsetting the small farms mentioned above, some of these are quite large operations, of up to 1,000 acres. These commercial farms include organic operations, since many commercial operations in California have both organic and conventional fields. According to 2019 California Strawberry Commission survey data, conventional strawberries represent $\sim 87$ percent of total strawberry acreage along the Central Coast, with the rest certified organic (cited in Bolda et al., 2019). These organic berries are marketed through conventional distribution channels.

The research reported herein is primarily based on qualitative interviews with such commercial growers. Prior reports on this research have shown that growers prioritize yield in cultivar choice and would be reticent to opt for a disease resistant cultivar in lieu of fumigation (Guthman, 2020). This article brings focus to the larger socioeconomic challenges face as it may affect cultivar selection. These interviews were conducted in 2018-2019 $(n=20)$ and in $2021(n=5)$.

Our sampling strategy reflects the significant difficulty of finding growers willing to be interviewed in this highly beleaguered industry. (To provide some perspective, one of us, Guthman, has been contacted by several researchers hoping to gain tips after having no success in obtaining interviews.) The research contained herein was essentially a subset of all of those we had successfully contacted and interviewed in earlier research. Leads for the earlier research came from county pesticide use permits when made available by county agricultural commissioners and otherwise relied on public internet searches. For this research, we began with all of those who had expressed willingness to be interviewed again - and who were still reachable. However, we omitted diversified growers, who are not the target of breeding efforts, and we limited the number of proprietary growers who exercise little choice in their cultivar choices which therefore allowed us to reach saturation more quickly (see below). This was in effect, then, a convenience sample and one that was over representative of growers who tend to cooperate with researchers for both social science and field trial research, but by that same criteria tend to be trend setters in the industry. Our final sample of 25 included 8 growers of

${ }^{3} 2020$ California Strawberry Acreage Report from the California Strawberry Commission (www.CalStrawberry.com). proprietary varieties; of these 25 growers, 11 had all conventional operations, 11 had mixed operations, and 3 had transitioned entirely to organic production, but, again, not in a diversified way.

Since the goal for the interviews was to achieve depth rather than establish statistically significant patterns, these were open-ended interviews, guided by a small set of predetermined questions. As it happens, this small sample was more than adequate to reach saturation, such that the last few interviews neither produced more themes, nor differences across grower characteristics, nor deepened understanding (Crouch and McKenzie, 2006; Hennink et al., 2017). Because of the nature of our questions, focused on grower plans, practices, and observations, rather than inner thoughts they held as persons, we in fact found no functional difference between what Hennink et al. describe as code saturation (having "heard it all") or meaning saturation (having "understood it all)," the latter capturing additional nuances or dimensions in the code. We transcribed and coded interview data with qualitative research software (initially NVivo, then Dedoose due to personnel changes), with themes following from the interview questions. We also employed some of the few open-ended responses obtained from a largely quantitative survey conducted in 2018 that assessed growers' management responses to soil-borne diseases and their likelihood to reduce fumigant use (Guthman, 2020). Our findings follow summary background of each of the major challenges gathered from prior research. Importantly, not all growers interviewed discussed these challenges or discussed them with the same amount of concern, but no growers controverted the existence of such challenges.

\section{RESULTS: SOCIO ECONOMIC CHALLENGES AND DISEASE RESISTANT CULTIVARS}

\section{Land}

Coastal California provides an ideal climate for strawberry production. Sandy soils provide important drainage, preventing build-up of moisture and salt. The Mediterranean climate allows unusual productivity. The near rainless months of May through November minimize susceptibility to molds and moisturegenerated pests and diseases. But summer heat is modulated by coastal fog, creating the conditions of "eternal spring," which elicits blossom production and improves fruit quality without excessive vegetative growth. In addition, the relatively mild climate makes possible an unusually long harvest season (Wells, 1996).

Over the years plant breeders have developed cultivars suitable to the various microclimates in the state and extended the season as long as possible. Short day varietals grow in winter in the southern part of the state; further north, day neutral varietals extend the harvest season by months (Darrow, 1966, $232)^{4}$. In some areas the season is so long that strawberry growers require 15 months to prepare land, plant, and harvest.

${ }^{4}$ Although planting are staggered by region, most of the crop is planted in fall or late fall for a late winter or spring harvest. Ventura (Oxnard) and Santa Barbara (Santa Maria) counties see some summer plantings as well, for harvest in the fall. These plants are kept in long cold storage (frigo plants) after propagation. 
Many such growers rotate land with vegetable growers who can grow leafy green crops in the remaining 9 months. But vegetable growers also often hold the master leases on land, and try to dictate to strawberry growers what they should do, including fumigating land with chemicals not strictly allowable for vegetable production (Guthman, 2016). Most strawberry growers lease a majority, if not all of their land.

The challenge is that strawberry land values are high, and the most suitable land is scarce. Values are high in part because of the innovations undergone by the strawberry industry itself: fumigation that eliminated rotations, plant breeding that extended the length of seasons, rotations with vegetable growers that eliminated remaining gaps in land use, and the displacement of plant propagation to other locations more suitable for such uses (Guthman, 2019). With agricultural land values generally based on the capitalization of expected income from any piece of land, land owners can demand high rents to access it (Guthman, 2004). Accordingly, annual land rent for strawberry land climbed from $\$ 150$ per acre in 1969 to $\$ 2700$ in 2014 (with many growers paying more than that), more than doubling the percentage of total production costs (Tourte et al., 2016). Land with good water sources are particularly valuable. Bidding wars for good strawberry land have been reported, as well as the practice of major players in the industry scouting for and monopolizing prime strawberry land (Guthman, 2019). Strawberry land values are also high because the same climate so ideal for strawberry production is also attractive for suburbanites. Most of the fruit growing regions have seen extensive suburban development over the past several decades, both housing and shopping malls. Farmland financialization (and speculation) has also affected strawberry regions, with at least one investment group having purchased several parcels for strawberries, perhaps future commercial development (Guthman, 2019). High land values means farmers must maximize crop value per acre to compete for land (Olimpi et al., 2019, 3).

Yet, attempting to grow strawberries outside of the prime regions within California has apparently not been efficacious. Although some growers have been able to find greenfields, "virgin land" in what was previously pasture land, poorly drained soils and hotter climates tend to induce stress in strawberries, stresses that novel pathogens such as Macrophomina prey upon (Guthman, 2016, 2019). Moreover, without efficacious fumigation, growing strawberries on already damaged parcels risk high disease loads, which are extremely difficult to control with non-chemical means, including disease resistant pathogens.

Growers we interviewed corroborated this ongoing problem with the cost and scarcity of good land. One grower shared that a newly established indoor operation for strawberries, which uses soilless substrate as a growth medium, was rational in the area only because the particular piece of land on which it was built was mediocre and easily flooded. Often, though, growers expressed this as problem of high fixed costs that make profits hard to come by and make it nearly impossible to rotate crops except in organic programs where higher prices compensate for land out of profitable production for a year. They also expressed it as a problem of accessing land often controlled by others, whether the more powerful shippers, who reportedly scout for the best land, or vegetable growers, who hold master leases and benefit from the residual effect of fumigation in the strawberry fields. These arrangements make it particularly challenging for smaller (and largely Latinx) growers to access land. In regard to the latter, as one noted: "Large growers can also build better alliances with vegetable growers because they can do better business and access large chunks of land, rather than the small grower who only has a few acres. These personal relationships with vegetable growers are very important because often they hold the master leases, not us."

Land costs contribute to growers' desires for the high-yielding cultivars that have long been a priority of breeding (Darrow, 1966; Wilhelm and Sagen, 1974; Baum, 2005). "The only thing that can bring our costs down is through yield," said one grower. Another expressed that given the increasing costs of rent (and labor-see below), the highest priority when choosing a new cultivar is to maintain acceptable volumes, "having a good volume allows us to withstand the prices of land and labor." Even the presence of disease in land usually does not affect these preferences for high-yielding varieties, with some growers expressing they would rather give up land that has disease than try disease resistant varietals with less yield. For example a grower noted that before giving up yield, they "would go on a hunt and search for fresh ground," and indeed had already "walked away from a couple of ranches" in Baja California that were diseased. Notably, they were able to do so because "the soil down there is abundant." With land expensive and hard to come by, moving on is not often an option in Alta California. Yet, as previously reported, many growers claim they would be more inclined to move to soilless systems than use disease resistant cultivars as a disease management strategy (Guthman, 2020). Interestingly, soilless systems are more capital intensive than conventional systems, adding to grower fixed costs, but when involving trays in open air (to take advantage of climate) can allow fruit to be grown on poorer pieces of land. According to some growers, however, a turn to soilless systems would require different breeding efforts: rather than disease resistance, a varietal that can uptake nutrients from other media and potentially handle indoor conditions, as well.

\section{Labor}

By sheer volume of production, strawberries require a tremendous amount of harvest labor, with harvest labor representing $<60 \%$ of total costs (Tourte et al., 2016). In addition, labor must be highly tuned to the specificities of the crop. Since berries are perishable, the harvest must be timely and reliable; since they are delicate, prone to bruises and molding, the harvest must be conducted with care; since the market imposes aesthetic quality standards of size, shape and color, harvest laborers must be selective in what they pick; and since the crop is inherently expensive to grow, labor costs must be cheap enough for berries to be affordable for consumers and profitable enough for farmers (Wells, 1996). Crucial for the industry's success has been forms of labor control that ensure loyalty and care while keeping costs as low as possible. Such controls are particularly important because of the sizable capital outlays of strawberry production, including starts, fumigation, and other ground 
preparation, making a maximum harvest crucial to recouping investment (Wells, 1996).

The standard industry practice to achieve some of these aims has been paying workers by piece rate or by a combination of piece rates and hourly wages. Paying workers by the box has incentivized productivity amidst otherwise uncomfortable field conditions. Although piece wages effectively reduce wages on a per unit basis, grower claim these arrangements satisfy workers who can make more money in a short time than they might with an hourly wage (Guthman, 2017b). Since piece rates lend themselves to quality control problems, however, growers have also implemented systems of close supervision. Foremen walk the rows, scrutinizing the quality and rate of harvest while checkers not only kept tabs on boxes brought to the truck (as a basis of piece rate wages), but also spot-check baskets for bad fruit (Wells, 1996).

This system has been challenged by two developments in the agricultural labor market. One is changes in labor laws that are precipitating higher wages. (Piece rate workers must still make enough on piece rates to meet the minimum wage.) In 2016, California passed new minimum wage and overtime laws, with specific provisions for farm work ${ }^{5}$. The laws mandate that the hourly minimum wage rise to $\$ 15$ by 2023 and eliminate an allowance that field workers can work up to $10 \mathrm{~h}$ per day or $60 \mathrm{~h}$ per week without overtime wages; as the program is phased in, the maximum hours per week without overtime pay will drop to 40 (Bolda et al., 2019). Although piece rates for faster workers often exceed the state's current legal requirement, higher base wages make piece rates less incentivizing for all but the fastest workers, while the overtime provisions may take away flexibility that growers have relied on and perhaps necessitate more sporadic hiring at crucial moments. Increases in California State payroll taxes, workers' compensation insurance and other obligatory labor costs, such as housing and transportation have also added to the cost of labor (Bolda et al., 2019).

The other development is the labor shortage precipitated by stricter border controls. Since the 1990s, several measures have been taken by the federal government to fortify the US-Mexico border and deter crossings. These measures, including Operation Gatekeeper in California and the Alien Transfer Exit Program, have multiplied budgets for border patrol agents, created fences and walls, and installed military surveillance devices to enable the apprehension of would-be migrants (Nevins, 2001; De Leon, 2015). Border fortification has made it increasingly dangerous and costly to cross, has all but ended circular migration patterns, and altogether decreased migration of agricultural workers (Fan et al., 2015). In addition, strawberry growers compete with other industries and crops. Since strawberries are infamous for arduous labor conditions, requiring workers to bend over to pick crops (Holmes, 2013), given the opportunity experienced workers will choose to work in vegetables or other berries where they can pick

\footnotetext{
${ }^{5}$ This new bill would require that beginning in January 1, 2022, any work performed by an agricultural worker, in excess of 12 hours in one day to be compensated at the rate of no less than twice the employee's regular rate of pay. Chapter 313 of Bill no 1066. California Legislative information. https://leginfo. legislature.ca.gov/faces/billTextClient.xhtml?bill_id=201520160AB1066.
}

standing up, or take construction jobs that are far more lucrative. Many growers have not completed their harvest or abandoned fields already planted due to this labor shortage (Guthman, $2017 b)$. Others have addressed the shortage by resorting to the $\mathrm{H} 2 \mathrm{~A}$ program, a guest worker program that brings workers from Mexico on a short term basis. But this program requires growers to supply transport and housing, increasing their labor costs. With shrinking profit margins due to both higher costs and flat prices (a phenomenon described further below), growers are reluctant to provide more than modest increases in piece rates to attract more workers (Guthman, 2017b).

Grower concerns about the overall costs of labor were corroborated in this study: "every single one of our costs is going up in the state of California with all the laws that are being passed, like on the labor with the $40 \mathrm{~h}$ work week. I mean our costs are going through the roof." As with land, the high cost of labor reinforces grower desire for high yields. "We want to pay over minimum wage, but volume has to match this to make a profit," one grower asserted. "The only way we can bring some of the costs down is through yield," said another. A third: "we cannot pay people without good yields."

At the same time, growers discussed specific attributes of cultivars that can help manage labor costs. Cultivars that produce a small, but productive plant, with large berries that are visible on the plant and easy to remove allow workers to pick quickly. "[With this variety] the plants stay small and this allows pickers to work better... What I mean is that it promotes a better worker performance." Other cultivar characteristics can impact labor costs negatively, such as abundant runner (i.e., stem) production. Not only does runner growth stunt fruit productivity; runners require cutting. One grower told us that since labor is so expensive his profits would increase tremendously, if he could "avoid cutting runners up to 10 times a year." "When you net the stuff out," he said, "Monterey [a cultivar] has higher yield but when you are losing more berries and losing to labor costs, there is no advantage." Another grower similarly stated: "If you have a variety that has a lot of runner production, that variety costs you more money, because we have to cut that runner and we pay our workers by the hour for that job. The more runner you have the less fruit you will produce too, so that plant becomes more expensive."

Somewhat counterintuitively, attributes of productivity, size and visibility also figure large in growers' efforts to manage the labor shortage: workers are attracted to farms with highly productive plants. This is because abundant, easy-to-harvest berries allow workers to earn more per hour on piece rates. As put by one grower, "labor is such a huge factor in all these varieties, it can't be so small that people won't make money harvesting it. They just won't come ... they have to make a certain number of boxes per hour so there's a certain size window that you like, the bigger the better." So significant are cultivars in attracting workers that many growers say that workers will inspect their berries before coming to work for them and if the conditions are good bring others. "If we have one worker right now and he thinks he is making more money, he can get on the phone and get people to come within the hour," said another grower. The counterintuitive finding that high 
productivity works for both grower and worker alike is solely because workers are primarily paid on piece rates rather than hourly wages.

Growers further noted the advantages of cultivars that are bred to produce berries over long periods of time or produce berries at the beginning and end of the season. These attributes, they say, aid recruitment and retention. "If they can make 25 cents an hour somewhere else they leave. If you can hold up with a fairly decent variety they will stay with you 'til the end of the season," said a grower. Growers also noted their preference for varieties that peak at different times to help with the labor shortage. They did not, however, mention that disease resistance could also play a role in attracting workers, insofar as that would reduce the number of berries workers have to cull.

Importantly, though, growers are not of one mind regarding the use of productive cultivars as a way to manage labor shortages. One grower spoke of dropping the highly productive Monterey variety because it would come in when there would be too many berries and he didn't have the personnel to pick them.

Being a small farmer I couldn't pay the wages that these bigger guys were paying. So when that Albion came in I can keep my crew there and it was just a steady pick. We just kept marching on. The Monterey comes in, you better have the personnel sitting on the sidelines in order to jump in and start helping you out because you will get behind. And once you get behind on that thing forget it, you will be chasing your tail for the rest of the season

Another stated that more productive berries could stretch the picking schedule-workers have to pass through a field many times since they do not all ripen at the same time-to every 4-5 days which means that many berries would over-ripen.

....it's manageable, a variety that you can pick say 300 to 400 trays at the most in one round, one pick. But if you start doubling that and you still gotta make two rounds that week, there's no way. Impossible. Because your best pickers can only pick maybe 200 trays a day, maybe. The average is probably 120 or 130 something, in a $9 \mathrm{~h}$ day. But if the variety was produced at a little more reasonable rate and they could sell it at a higher price, we could go longer. But can't, not anymore. Because by the second or third day they're now picking overripe fruit. And [the workers] don't get paid for it.

In other words, in the context of absolute labor shortage, productive varieties work at cross purposes to having all good berries picked. For that reason, growers also mentioned that competing with other growers for labor, by using a more productive variety, was not good for the industry as a whole.

\section{Marketing Intermediaries}

Historically, in California, few commercial specialty crop growers have marketed their own produce (Stoll, 1998), a pattern that has held true for strawberries. Instead, most commercial strawberry growers sell on contract to either stand-alone shippers or "grower-shippers" that both grow and market their own produce (Baum, 2005; Guthman, 2017a). Shippers generally provide cooling, marketing material, coordination with distributors, and otherwise mediate grower access to markets. Over time, the number of shippers has consolidated. With their oligopsonistic position, they are increasingly able to set terms more beneficial to themselves (Guthman, 2019). Most growers, in fact, are tied to one shipper, with which they have various levels of dependence. For example, "custom growers" are paid by shippers to produce strawberries regardless of outcome. The shippers finance these operations in their entirety and sometimes even control the ground lease. In return, custom growers receive a flat management fee or are paid by the acre. But such contracts are fairly rare. More commonly, nominally independent growers sell to shippers through marketing contracts, and growers are paid by the box at a fluctuating market rate, determined by the shipper. The term independent should thus be taken with a grain of salt. Shippers may arrange land leases for some of their contract growers and even hold the lease. Some shippers may also provide financing to their contract growers, with repayments deducted from sales returns. In addition, shippers may also mediate access to pest control services, to farm labor contractors, and to the nurseries from which growers purchase starts (Guthman, 2017a).

In return, growers not only pay sales commissions, but also must purchase marketing materials from shippers (e.g., boxes), pay cooling fees, and in some cases significant management fees (up to 18\%). All of these fees necessarily cut into grower profit margins. More significantly, growers must abide by various quality stipulations. Of primary significance is the requirement of some shippers that growers use only proprietary varieties that those shippers have developed, as opposed to varieties that have been developed by the University of California and are publicly available. For perspective, in 1955, 95\% of growers planted university varieties (Baum, 2005), a percentage that declined to $61 \%$ by $2021^{6}$. Growers must pay licensing fees for plants in addition, which are much steeper for proprietary varieties that return to the shipper who developed them, although it is important to note that licensing costs for the use of public university varieties are significant enough to generate ample revenues for the university ${ }^{7}$. Furthermore, all shippers impose grading standards on growers, and some are quite stringent, manifesting in cull rates of up to $30 \%$ of berries grown. Shippers with higher grading standards and proprietary berries tend to have developed brands associated with high quality berries, so higher cull rates and licensing fees are potentially offset by higher prices (Guthman, 2019).

Our research confirms that shippers and growers can have different priorities for cultivars. Generally, shippers favor varieties that they deem more marketable, namely those that fulfill certain aesthetic requirements for size, shape, color, and shelf life. "Biggest and prettiest is all those big guys care about," said one grower. Shippers do not necessarily ignore flavor, however. One grower-shipper noted that a bad tasting variety, or one that rots quickly, will turn consumers away from strawberries

\footnotetext{
${ }^{6}$ This is taken from the California Strawberry Commission 2021 Acreage Survey, found at https://www.calstrawberry.com/Portals/2/Reports/Industry\%20Reports/ Acreage\%20Survey/2021\%20Acreage\%20Survey.pdf.

${ }^{7}$ According to a media report, the University of California earned $\$ 50$ million in strawberry licensing fees between 2004 and 2013 Charles (2014).
} 
and toward other fruit. These aesthetic concerns are particularly important to shippers in mid-summer when berries compete with other summer fruits. Growers' preferences for cultivars often do not align with shippers', though. As discussed above, there is great pressure from land and labor markets for growers to choose the most productive varietal. Growers might also prefer cultivars that work best with their field conditions, including evidence of disease infestation. Sometimes, however, growers prefer less productive and what they see as tastier varieties as a matter of pride. "I wanted berries coming out of my ranch to be nice. I did not like the Monterey because it had no flavor it had no taste." Another grower said: "I don't want to grow strawberries that people don't want to eat. That doesn't do me any good just because, and there are berries that I could grow that I could get 10,000 trays an acre. But it's a nothing, it doesn't have anything to it."

The question then becomes whether and how much shippers dictate what varieties growers plant. Our interviews show that shippers' stipulations and fee structures can effect cultivar selection, but in variable ways. Shippers with their own proprietary varieties necessarily require growers to use them, for which growers pay the considerable licensing fees and face higher culling rates. Some growers who sell to one of the firms requiring proprietary varietals reported that they were able to choose among several different cultivars available, opting for those that work best with their field conditions, while others reported that the shipper allocated varieties to growers in fixed percentages. Shipper constraints are even more variable for growers who plant public (university) varietals. Some growers reported shippers requiring that that the grower plant certain varieties, and others reported that shippers incentivized the production of certain varietals by the prices they would pay. Yet other growers said that shippers do not differentially pay by the cultivar, in part because marketing has not emphasized cultivars and thus the general public does not recognize them (except for farmers' market shoppers).

Shippers' stipulations that a particular variety be grown can work adversely for growers who find that other varieties may be better suited to a grower's production conditions, including disease infestations. For example, a grower in an area that has been severely affected by Fusarium wilt was frustrated by the pressure to grow the Monterey variety instead of his preferred San Andreas, which he claimed was "more forgiving to disease pressure." However, when shippers do not stipulate cultivar choice, and especially when they set prices by volume and not by cultivar, growers tend to choose the most productive varieties. Under these conditions, they make more money with every additional berry they sell. But there is a flip side of this freedom to grow what they want: shippers tend to set prices they will pay to growers around certain expectations of productivity, making it extremely challenging for growers to plant berries that they prefer for other qualities, whether disease resistance or flavor. One grower stated with regret about transitioning out of what he saw as a far superior variety to get his volume up and stay competitive. "I grow Monterey [a less flavorful variety] to make up for the production loss on Albion. The overhead cost is so high, if the prices people are paying keep going down, I might as well quit." Frustration with low prices and certain aesthetic standards is in fact one of the reasons why a number of growers prefer to sell independently, allowing them to prioritize taste as opposed to cosmetic perfection. Growers who are particularly dependent on shippers for their financing and access to land, which is not uncommon, operate in particularly constrained conditions of cultivar choice and tend to do what shippers ask.

\section{Overall Market Conditions}

The challenges discussed thus far tend to incentivize growers opting for practices that maximize productivity. With land being expensive and scarce, labor being scarce and paid by the piece, and shippers extracting significant portions of farm revenues, obtaining high yield from a given piece of land makes sense for individual growers, who are, in effect, competing with each other for land, labor, and markets. But, in fact, another major socioeconomic challenge facing growers is poor prices resulting from overproduction.

To provide some context, the industry saw huge growth between 1960 and 2014-when acreage more than tripled, production increased ten-fold, and the value of production in real dollars increased by $424 \%$ in Monterey and 593\% in Santa Cruz Counties, the original center of strawberry production (Tourte et al., 2016) ${ }^{8}$. Equally striking was that net returns for growers were exceptional as well, no doubt a reflection of the long season growers in these two counties enjoy. Markets were able to keep up with productivity in large part due to the California Strawberry Commission and shippers to increase demand for fresh market strawberries (Baum, 2005). Although net returns vary considerably, in 2010 conventional growers were typically making profits of nearly $\$ 8,000$ per acre, with some exceeding that (Tourte et al., 2016).

Beginning around 2013, however, these favorable market conditions began to falter, indicated by many growers going out of business or reducing their acreage, due to many of the conditions described above. According to the 2017 U.S. Agricultural Census (the most recent as of this writing,) the total number of California strawberry growers shrunk from 995 in 2012 to 676 in 2017. Subtracting farms (or patches, more accurately) of $<5$ acres, better reflecting the number of commercial growers, these numbers declined from 375 to 241 (United States Bureau of the Census, 2012, 2017). Those years also saw significant decline in acres, especially in the southern part of the state, with acres planted dropping from an all-time high of 40,816 in 2013 to 31,640 in 2015, rebounding somewhat to 36,487 , reportedly due to consumer demand ${ }^{9}$. During roughly the same period, production grew from 195,011,537 trays in 2013 to at an all-time high of 224,491,465 trays in 2018, even with the drop in acres. A change from 4,478 trays per acre to 6,634 trays an acre represents a $48 \%$ increase in yield per acre over 5

\footnotetext{
${ }^{8}$ According to Tourte et al., this increase in the overall value of strawberry production reflected enormous increases in tons per acre, from 9 to 30 in Santa Cruz County and 12 to 37 in Monterey.

${ }^{9}$ These figures derive from the 2013, 2015, and 2021 California Strawberry Commission Acreage Survey. Unfortunately, only the latest is available on the website at https://www.calstrawberry.com/Portals/2/Reports/Industry \%20Reports/Acreage\%20Survey/2021\%20Acreage\%20Survey.pdf.
} 
years, largely reflecting the use of higher yield varieties. Prices have more or less stayed steady, however, not keeping up with the increased cost of everything else ${ }^{10}$.

In our interviews, growers lamented this situation. A grower described the status of the industry as "rough," and identified oversupply related to an increased focus on productivity in breeding as a problem for the industry: "Newer varieties are so much more productive, techniques are so much more productive, the total volume has not really decreased very much. So we are hurting ourselves with the overproduction." Another stated: "We want these varieties to give out more numbers and last longer but it's hurting us in the long run... It seems like people think that if I plant 100 acres and make such amount of dollars, if I put 200 acres in, I'm going to make double that and it don't work that way." Some growers characterized this cycle of overproduction and low prices as severely damaging to the industry: "the problem now is the growers are having too much production and it is killing them, said one. Another, acknowledging that "the only thing that helps paying for anything is volume," also referred to it as "a death spiral." Growers understand, in other words, that the prioritization of individual decisions in the context of socioeconomic challenges presents a major collective action problem (Guthman and Zurawski, 2020).

This next quote is thus instructive. When asked why productivity is such a focus when prices are so low, one grower responded as follows:

That's a very good question. I think if we had the same overproduction that we had last year, if you ask me as a grower, what would you prefer to do [I would say] have a less productive variety or sacrifice acreage that you planted in order to control the abundance of product, or the supply of product, I would choose controlling the supply of product..... We're gonna grow only what the market can absorb at a decent price. Supply control, I think that's ideal but nobody is going to give into that idea.

The grower is probably correct that supply control would take some convincing, as would probably other alternatives to which our findings lead.

\section{DISCUSSION: SUMMARY AND ALTERNATIVES}

The appearance of soil-borne pathogens in California, along with the phase-out of methyl bromide and continuing tightening of regulations for the use of fumigants, have sparked tremendous need among scientists, extension agents and growers to develop effective alternatives for disease management (Goodhue et al., 2005; Norman, 2005; Mayfield and Norman, 2012). Among these alternatives, the development of disease resistant cultivars are receiving a great deal of investment and, indeed, hold promise for contributing to a broader array of disease management strategies. At the very least, their development reflects a transition in the making (Elzen et al., 2011).

\footnotetext{
${ }^{10}$ Time series volumes, volumes per acres, and prices can be obtained from https:// www.calstrawberry.com/en-us/Market-Data/District-Report.
}

Nevertheless, as we have highlighted, strawberry growers operate under significant socioeconomic constraints in California, many of which are beyond their control: land suitable for long strawberry seasons is scarce and costly, competes with other land uses, and is sometimes monopolized by some of the most powerful players in the industry; labor costs have increased significantly due to both border politics and new laws and regulations, the latter of which importantly improve conditions for farm workers, but cut deeply into growers profitability; shippers provide markets for growers, but set prices favorable for shippers, charge various fees, and impose various quality stipulations, such that many growers have to cull a certain percentage of what they grow. Moreover, since many growers are beholden to shippers for credit, land and other materials, they must often abide by shipper wishes, which may steer them away from a variety of disease management practices, including disease resistant cultivars. At the same time, due to the many technological successes of the strawberry industry, including plant breeding, the industry is highly prone to over-production, which exerts downward pressure on grower prices and pushes many growers out of business. Growers we interviewed for this study corroborated these remain significant challenges, so much so that several have exited the industry all together. These political economic constraints are thus a major source of lock-in, arguably even stronger than path dependencies stemming from patterned behavior (cf., Wilson and Tisdell, 2001; Magrini et al., 2016).

We have also shown that growers recognize the role commercial cultivars play in exacerbating or mitigating these challenges. Most growers, that is, see high-yielding varieties as crucial to their economic viability, allowing them to maximize output of their existing land, attract and retain workers during a time of labor shortages, and maximize revenues from shippers that pay by volume. This finding is in keeping with similar studies that have examined grower cultivar choice in the context of high disease loads (Vanloqueren and Baret, 2008). According to their study, growers prioritized cultivar qualities related to yield, commercial quality and earliness over disease resistance (p. 439). At the same time, many of the growers we interviewed acknowledge that the focus on individual farm productivity works at cross purposes to the problem of poor prices that arises from over-production, posing a deadly cycle that threatens the continuity of many growers in the industry. Growers are in effect competing for land, labor, markets, and high prices, in classic beggar thy neighbor fashion (Olimpi et al., 2019).

What role, then, do disease resistant varietals play in managing disease, on behalf of reducing the use of fumigation, within these socioeconomic conditions? Disease resistant varieties do not at face value address the concerns voiced by most growers, which with a few exceptions go beyond managing for soil-borne diseases. Although soil-borne diseases are a critical issue facing growers, growers also know that fumigation is still available, and, as a result, appear more daunted by other challenges. Yet, as Brummer et al. (2011) have suggested, participatory approaches to plant breeding can allow for growers' socioeconomic concerns to be incorporated into the breeding process. As it happens, some of the newest varieties coming out of the University of California's 
breeding program promise disease resistance and yield, as well as flavor and fewer runners, hitting several of the traits currently desired by growers ${ }^{11}$. The question then becomes how growers can maintain economic viability while adopting disease resistant cultivars as a disease management strategy.

It is already recognized that use of disease resistant cultivars alone is insufficient as a disease management strategy; that it will take integrating a number of approaches, including improving soil health, rotating crops, resting the land, among others. But even if growers incorporated all of these approaches they would still face pressures of land markets, labor markets, intermediaries, and low prices. Our findings likewise suggest that if some of the other pressures were mitigated, growers might be more inclined to experiment with and adopt disease resistant varieties, in combination with these other approaches. Put differently, if growers were not competing for land and labor and squeezed by shippers they would have more leeway in adopting disease resistant cultivars and incorporating them in broader management strategies that include other techniques currently in development. Following Vanloqueren and Baret (2008), escaping "lock in" requires exogenous forces. So what kind of approaches might help mitigate these pressures?

One might think that heightening restrictions on fumigations even further could reduce fumigation. However, the aftermath of the methyl bromide phase-out has shown that removing fumigants and imposing strict mitigating strategies, do not necessarily reduce fumigation or incentivize growers to change practices. In fact, the use of chloropicrin increased dramatically (Guthman, 2016). More significantly, according to JiménezSoto's unpublished research, more fumigation restrictions have contributed to grower overall discouragement and desire to abandon farming altogether. While such technology-forcing approaches generally have the advantage of producing a level playing field of experimentation, it puts all of the burden on growers who must incorporate yet one more thing to meet the many regulatory demands put on them for which they receive no financial support.

With land and labor markets especially difficult to address, the most promising policy avenues seem to therefore lie with support of grower revenues. This could take the form of supply management-withholding some production to prop up prices, tailored to the needs of the twenty-first century (Graddy-Lovelace and Diamond, 2017) — and what one grower called "a very smart move." Alternatively, it could take the form of economic support for transitional lands. Either approach, of course, would require the industry to act more collectively than individually, which is

\footnotetext{
${ }^{11}$ https://www.plantsciences.ucdavis.edu/news/uc-davis-releases-5-newstrawberry-varieties-publicly-available-plants-will-help-farmers
}

no easy feat. But critiques of the productivity treadmill, along with the increased pressures of disease and novel pathogens, suggest an opening for rethinking. As put by Graddy-Lovelace (2021), recognition of shared fate and interdependence could go a long way in creating collective social contracts. Policies and practices that encourage farmers to getting off the productivity treadmill, in other words, could go a long way on focusing the industry on its most critical exigencies: farming sustainably in the face of climate change, human health considerations, and maintaining their own livelihoods.

\section{DATA AVAILABILITY STATEMENT}

The data presented in this article are not readily available because it is human subjects data that were collected under the premise that any personal identifying information would not be shared. Requests to access anonymized (redacted) versions of the data should be directed to Julie Guthman, jguthman@ucsc.edu. But will have to be cleared with the University of California, Santa Cruz Institutional Review Board.

\section{ETHICS STATEMENT}

Since this study involved human subjects, it was reviewed and approved by Office of Research Compliance Administration, University of California, Santa Cruz. Written informed consent for participation was not required for this study in accordance with the national legislation and the institutional requirements.

\section{AUTHOR CONTRIBUTIONS}

JG conducted the majority of interviews, oversaw transcription and coding of those interviews, and wrote most of the manuscript. EJ-S conducted some of the interviews, transcribed, coded those interviews, and drafted portions of the manuscript containing new data. Both authors contributed to the article and approved the submitted version.

\section{FUNDING}

Research was supported by the USDA NIFA program, award \#2017-51181-26833.

\section{ACKNOWLEDGMENTS}

The authors wish to thank Madeleine Corich and Erica Zurawski for research assistance in transcribing and coding interviews.

\section{REFERENCES}

Baum, H. (2005). Quest for the Perfect Strawberry. New York, NY: iUniverse, Inc.

Bolda, M., Tourte, L., Murdock, J., and Sumner, D. (2016). Sample Costs to Produce and Harvest Strawberries, Central Coast Region. Available online at: https://coststudyfiles.ucdavis.edu/uploads/cs_public/e7/6d/e76dceb8-f0f54b60-bcb8-76b88d57e272/strawberrycentralcoast-2016-final2-5-1-2017.pdf (accessed November 27, 2017).

Bolda, M., Tourte, L., Murdock, J., and Sumner, D. (2019). Sample Costs to Produce Organic Strawberries, Central Coast Region. Available online 
at: https://ucanr.edu/sites/uguthccesc/files/312501.pdf (accessed August 3, 2021).

Brummer, E. C., Barber, W. T., Collier, S. M., Cox, T. S., Johnson, R., Murray, S. C., et al. (2011). Plant breeding for harmony between agriculture and the environment. Front. Ecol. Environ. 9, 561-568. doi: 10.1890/100225

Charles, D. (2014). Big Bucks From Strawberry Genes Lead To Conflict At UC Davis. The Salt: What's on Your Plate [Online]. Available online at: https://www. npr.org/sections/thesalt/2014/07/02/327355935/big-bucks-from-strawberrygenes-lead-to-conflict-at-uc-davis (accessed November 23, 2017).

Cowan, R., and Gunby, P. (1996). Sprayed to death: path dependence, lock-in and pest control strategies. Econ. J. 106, 521-542. doi: 10.2307/2235561

Crouch, M., and McKenzie, H. (2006). The logic of small samples in interview-based qualitative research. Soc. Sci. Inform. 45, 483-499. doi: 10.1177/053901840606 9584

Darrow, G. M. (1966). The Strawberry: History, Breeding, and Physiology. New York, NY: Holt, Rinehart, and Winston.

De Leon, J. (2015). The Land of Open Graves: Living and Dying on the Migrant Trail. Berkeley: University of California Press.

Department of Pesticide Regulation. (2013). Nonfumigant Strawberry Production Working Group Action Plan. Available online at: http://www.cdpr.ca.gov/docs/ pestmgt/strawberry/work_group/action_plan.pdf (accessed April 4, 2014).

Elzen, B., Geels, F. W., Leeuwis, C., and van Mierlo, B. (2011). Normative contestation in transitions 'in the making': Animal welfare concerns and system innovation in pig husbandry. Res. Policy 40, 263-275. doi: 10.1016/j.respol.2010.09.018

Fan, M., Gabbard, S., Pena, A. A., and Perloff, J. M. (2015). Why do fewer agricultural workers migrate now? Am. J. Agric. Econ. 97, 665-679. doi: 10.1093/ajae/aa $\mathrm{u} 115$

Galt, R. E. (2013). From homo economicus to complex subjectivities: reconceptualizing farmers as pesticide users. Antipode 45, 336-356. doi: $10.1111 /$ j.1467-8330.2012.01000.x

Gareau, B. J. (2008). dangerous holes in global environmental governance: the roles of neoliberal discourse, science, and California Agriculture in the Montreal Protocol. Antipode 40, 102-130. doi: 10.1111/j.1467-8330.2008.00 572.x

Goodhue, R. E., Fennimore, S. A., and Ajwa, H. A. (2005). The economic importance of methyl bromide: Does the California strawberry industry qualify for a critical use exemption from the methyl bromide ban? Rev. Agricult. Econ. 27, 198-211. doi: 10.1111/j.1467-9353.2005.00221.x

Graddy-Lovelace, G. (2021). Farmer and non-farmer responsibility to each other: negotiating the social contracts and public good of agriculture. J. Rural Stud. 82, 531-541. doi: 10.1016/j.jrurstud.2020.08.044

Graddy-Lovelace, G., and Diamond, A. (2017). From supply management to agricultural subsidies-and back again? The US Farm Bill and agrarian (in) viability. J. Rural Stud. 50, 70-83. doi: 10.1016/j.jrurstud.2016.1 2.007

Guthman, J. (2004). Agrarian Dreams: The Paradox of Organic Farming in California. Berkeley: University of California Press.

Guthman, J. (2016). Going both ways: More chemicals, more organics, and the significance of land in post-methyl bromide fumigation decisions for California's strawberry industry. J. Rural Stud. 47, 76-84. doi: 10.1016/j.jrurstud.2016.07.020

Guthman, J. (2017a). Life itself under contract: rent-seeking and biopolitical devolution through partnerships in California’s strawberry industry. J. Peasant Stud. 44, 100-117. doi: 10.1080/03066150.2016.1217843

Guthman, J. (2017b). Paradoxes of the border: Labor shortages and farmworker minor agency in reworking California's strawberry fields. Econ. Geogr. 93, 24-43. doi: 10.1080/00130095.2016.1180241

Guthman, J. (2019). Wilted: Pathogens, Chemicals, and the Fragile Future of the Strawberry Industry. Oakland, CA: University of California Press.

Guthman, J. (2020). Strawberry growers are unlikely to forego soil fumigation with disease resistant cultivars alone. California Agricult. 74, 138-143. doi: 10.3733/ca.2020a 0021

Guthman, J., and Zurawski, E. (2020). "If I need to put more armor on, I can't carry more guns": the collective action problem of breeding for productivity in the California strawberry industry. Int. J. Sociol. Agricult. Food 26, 69-88. doi: 10.48416/ijsaf.v26i1.59

Hennink, M. M., Kaiser, B. N., and Marconi, V. C. (2017). Code saturation versus meaning saturation: how many interviews are enough? Qual. Health Res. 27, 591-608. doi: 10.1177/104973231666 5344

Holmes, G. J., Mansouripour, S. M., and Hewavitharana, S. S. (2020). Strawberries at the crossroads: management of soilborne diseases in California without methyl bromide. Phytopathology 110, 956-968. doi: 10.1094/PHYTO-11-19-0406-IA

Holmes, S. (2013). Fresh Fruit, Broken Bodies: Migrant Farmworkers in the United States. Berkeley: University of California Press.

Koike, S. T., Gordon, T. R., Daugovish, O., Ajwa, H., Bolda, M., and Subbarao, K. (2013). Recent developments on strawberry plant collapse problems in California caused by Fusarium and Macrophomina. Int. J. Fruit Sci. 13, 76-83. doi: 10.1080/15538362.2012.69 7000

Magrini, M.-B., Anton, M., Chardigny, J.-M., Duc, G., Duru, M., Jeuffroy, M.-H., et al. (2018). Pulses for sustainability: breaking agriculture and food sectors out of lock-in. Front. Sustain. Food Syst. 2:64. doi: 10.3389/fsufs.2018.00064

Magrini, M.-B., Anton, M., Cholez, C., Corre-Hellou, G., Duc, G., Jeuffroy, M.-H., et al. (2016). Why are grain-legumes rarely present in cropping systems despite their environmental and nutritional benefits? analyzing lock-in in the French agrifood system. Ecol. Econ. 126, 152-162. doi: 10.1016/j.ecolecon.2016.03.024

Mayfield, E. N., and Norman, C. S. (2012). Moving away from methyl bromide: political economy of pesticide transition for California strawberries since 2004. J. Environ. Manage. 106, 93-101. doi: 10.1016/j.jenvman.2012.04.009

Nevins, J. (2001). Operation Gatekeeper: the Rise of the "Illegal Alien" and the Remaking of the U.S.-Mexico Boundary. London: Routledge.

Norman, C. S. (2005). Potential impacts of imposing methyl bromide phaseout on US strawberry growers: a case study of a nomination for a critical use exemption under the Montreal Protocol. J. Environ. Manage. $\quad 75, \quad 167-176$. doi: 10.1016/j.jenvman.2004.1 2.002

Olimpi, E. M., Baur, P., Echeverri, A., Gonthier, D., Karp, D. S., Kremen, C., et al. (2019). Evolving food safety pressures in California's Central Coast Region. Front. Sustain. Food Syst. 3:102. doi: 10.3389/fsufs.2019.00102

Stoll, S. (1998). The Fruits of Natural Advantage: Making the Industrial Countryside in California. Berkeley: University of California.

Tourte, L., Bolda, M., and Klonsky, K. (2016). The evolving fresh market berry industry in Santa Cruz and Monterey counties. California Agric. 70, 107-115. doi: $10.3733 / \mathrm{ca} .2016 \mathrm{a} 0001$

United States Bureau of the Census (2012). 2012 Census of Agriculture. Available online at: https://www.nass.usda.gov/Publications/AgCensus/2012/Full_ Report/Volume_1,_Chapter_1_State_Level/California/ (accessed February 3, 2020).

United States Bureau of the Census (2017). 2017 Census of Agriculture. Available online at: https://www.nass.usda.gov/Publications/AgCensus/2017/Full Report/Volume_1,_Chapter_1_State_Level/California/ (accessed February 3, 2020).

Vanloqueren, G., and Baret, P. V. (2008). Why are ecological, lowinput, multi-resistant wheat cultivars slow to develop commercially? a Belgian agricultural 'lock-in' case study. Ecol. Econ. 66, 436-446. doi: 10.1016/j.ecolecon.2007.10.007

Wagner, C. H., Cox, M., and Bazo Robles, J. L. (2016). Pesticide lock-in in small scale Peruvian agriculture. Ecol. Econ. 129, 72-81. doi: 10.1016/j.ecolecon.2016.05.013

Wells, M. (1996). Strawberry Fields: Politics, Class, and Work in California Agriculture. Ithaca: Cornell University Press.

Wilhelm, S., and Paulus, A. O. (1980). How soil fumigation benefits the California strawberry industry. Plant Dis. 64, 264-270.

Wilhelm, S., and Sagen, J. E. (1974). History of the Strawberry: From Ancient Gardens to Modern Markets. Berkeley: University of California Press.

Wilhelm, S., Storkan, R., and Wilhelm, J. M. (1974). Preplant soil fumigation with methyl bromide-chloropicrin mixtures for control of soil-borne diseases of strawberries-A summary of fifteen years of development. Agricult. Environ. 1, 227-236. doi: 10.1016/0304-1131(74)90 $020-4$ 
Wilson, C., and Tisdell, C. (2001). Why farmers continue to use pesticides despite environmental, health and sustainability costs. Ecol. Econ. 39, 449-462. doi: 10.1016/S0921-8009(01)00 238-5

Conflict of Interest: The authors declare that the research was conducted in the absence of any commercial or financial relationships that could be construed as a potential conflict of interest.

Publisher's Note: All claims expressed in this article are solely those of the authors and do not necessarily represent those of their affiliated organizations, or those of the publisher, the editors and the reviewers. Any product that may be evaluated in this article, or claim that may be made by its manufacturer, is not guaranteed or endorsed by the publisher.

Copyright (ㅇ) 2021 Guthman and Jiménez-Soto. This is an open-access article distributed under the terms of the Creative Commons Attribution License (CC BY).

The use, distribution or reproduction in other forums is permitted, provided the original author(s) and the copyright owner(s) are credited and that the original publication in this journal is cited, in accordance with accepted academic practice. No use, distribution or reproduction is permitted which does not comply with these terms. 